\title{
An Overview of Presidential System at the Local Government Level in Nigeria
}

\author{
Prof. Adam A. Anyebe \\ Department of Public Administration, Faculty of Administration, Ahmadu Bello University, \\ Zaria-Nigeria \\ adamanyebe@gmail.com
}

\begin{abstract}
Presidential and parliamentary systems are the two universally acclaimed systems of organizing government of countries. The United States of America, many Latin American countries, and some African countries including Nigeria operate the presidential system. In many states, presidential system is adopted at the local government level which implies that there should be unity of the executive, separation of powers, and check and balances between the executive and legislature. This study, therefore, attempts to carry out an overview of the operation of the presidential system at the local government level in Nigeria. The paper reveals that there are some challenges which include the inability of the legislature to exploit the instrument of checks and balances provided in the Guidelines, rules and procedures as well as the constitution to check the excesses of the executive at level of government at times. For the local government to function effectively in the country, the executive and the legislature at that level should be imbibe the spirit of presidentialism
\end{abstract}

Keywords: Presidentialism, Parliamentary System, Local Government, Executive, Legislature, Judiciary

\section{INTRODUCTION}

There are two universally acclaimed systems of organizing government of countries. These are the parliamentary or West minister model and the Presidential system. A country may adopt either of the two, modifies it to suit local peculiarities or as it does happen in France, adopts the combination of the two to make a hybrid.

A parliamentary system of government has bicephalous political executives. In this case the executive power of the government is shared between two personalities in which, according to some writers, a distinction is made between dignified and effective aspects of government. The dignified aspect revolves around a ceremonial leader, i.e. the head of state who may merely be a titular president or a constitutional monarch, while the effective aspect rests on the prime minister. The prime minister and his team of ministers are all members of parliament and are all therefore collectively responsible to it. Thus, the right of the prime minister to govern depends on the majority support he and his cabinet enjoy in parliament hence the phrase, 'Parliamentary government.' In such parliamentary government, the duties of the head of state are largely honorific: receiving foreign dignitaries, bestowing honours, opening parliamentary session etc, while the prime minister actually rules. Britain, Canada, India, Italy, Japan are among the countries which operate parliamentary government. Nigeria operated it until 1966.

The presidential system with its monocephalous executive is different. Here executive authority and leadership are vested in a single individual, the president, who is the chief executive. He is elected directly by the people and he is independent of the legislature. He and his ministers he appoints are not members of the legislative organ. The ministers he appoints are directly responsible to him while he takes responsibility for the political and economic direction of the country. The U.S., many latin American countries and some African countries including Nigeria operate the presidential government.

Three basic elements make the presidential system what it is and indeed without them there will be nothing but a personal rule of an individual who has usurped power or who has manipulated the electoral system to put himself in power. The basic elements are:

The unity of the political executive as characterised by a single chief executive who exercises both nominal and real authority; 
$>$ The clear separation of legislative, executive and judicial powers of government; and

The concept of checks and balances.

This study therefore, attempts to carry out an overview of the presidential system of government at the local government level in Nigeria to show how the three elements give meaning to the system.

\section{Method of Data Collection}

The data used in the study were collected from local government publications, journals, internet materials and other relevant government publications.

\subsection{Classical Operation of the Presidential System}

(a) Unity of the Executive: The monosepalous (single) political executive is that person in whom all executive powers, both nominal and real, are vested. Because of the enormous power vested in such an individual some writers are inclined to describe him as a king without a crown.

The unity of executive powers may have been informed by the need to prevent clash of interest and personality which sometimes characterizes the operation of the parliamentary system.

(b) Separation of Legislative, Executive and Judicial Powers: The doctrine of separation of powers as understood was a seventeenth and eighteenth century political doctrine developed to protect liberty of the ruled and prevent tyranny. It first developed from the political theory of John Locke, who agreed that it was necessary to confer legislative and executive powers on different organs of government, namely the legislature and the executive because the legislature by its nature would act at intervals while the executive functions constantly. But Locke cautioned against any attempt to vest both legislative and executive powers in the same body. He noted that it may be too great a temptation to human frailty, apt to grasp at power, for the same persons who have the power of making laws, to have also in their hands the power to execute them, whereby they may exempt themselves from obedience to the laws they make and suit the law, both in its making and execution to their own private advantage.

The doctrine of separation of powers was further developed by one French Jurist, Charles Louis de Second ant, Baron de la Brede et de Montesquieu. The essence of the doctrine according to Montesquieu, is that the liberty of the citizen needed state protection and the only way to do this effectively was to distribute the three functions of the state among three different organs. A concentration of all these powers in the same body would clearly result in the suppression of political liberty of the people. As he noted in his The spirit of the laws, published in 1748:

When the legislative and executive powers are united in the same person, or in the same body of magistrates, there can be no liberty; because apprehension may arise, lest the same monarch or Senate should enact tyrannical laws, to execute them in a tyrannical manner. Again, there is no liberty if the judiciary power be not separated from the legislative and executive. Were it joined with the legislative, the life and liberty of the subject would be exposed to arbitrary control; for the judge might behave with violence and oppression. There would be an end of everything, were the same man or the same body, whether of the nobles or of the people, to exercise those three powers, that of enacting laws, that of executing the public resolutions, and of trying the causes of individuals (Gboyega, 1987).

Furthermore, Montesquieu took a dim view of human nature and in anticipating Lord Action's famous dictum "Power corrupts and absolute power corrupts absolutely", he rightly concluded that man has the innate urge to abuse his power. The only way therefore to check him is to establish and maintain a moderate government where power must be checked by power (Okoli, 1998).

Nowhere did the writings of Locke and Montesquieu have profound impact than in the United States of America where the doctrine of separation of powers formed one of the pillars of the constitution. The Founding Fathers of the American constitution intended to creat a strong national government. But in order to preserve the liberty of the citizens and check the ambition of public officials, they fragmented the authority of government among three groups of officials legislative, executive and judicial each of which was empowered to check the selfish ambitions for political powers, of the other. In the Federalist Paper (No 51) James Madison, one of the greatest American constitutional theorists, wrote that The great security against a gradual concentration of the several powers in the 
same department, consists in giving to those who administer each department the necessary constitutional means and personal motives to resist encroachments of the others (Okoli, 1998). Ambition must be made to counter ambition.

In line with the above, the American constitution does not only divide the powers of government into three main branches; it also encourages by design, each branch of government to pursue its own ambition to collide and interfere with the other branches. The same situation exists in Nigeria.

From the historical discussion above it would appear that the doctrine of separation of powers suggests at least three things:

$>$ That the same Persons should not form part of more than one of the three organs of government e.g. that the President or his ministers who constitute the executive organ should not be members of the legislative organs;

$>$ That one organ of government should not control or interfere with the work of another, e.g. that the judiciary should be independent of the other two organs or that the ministers should not be responsible to parliament;

$>$ That one organ of government should not exercise functions belonging another organ, eg the executive should not have legislative powers.

(c)Concept of Checks and Balances: It has been observed that a presidential constitution that espouses the doctrine of separation of powers, as the American constitution does also ensures that there is room for each organ to interfere with the acts of the other organ, i.e to check it in order to put it in proper balance. While no organ is dependent on the other for the exercise of its authority in its area of jurisdiction, none can operate without sharing some of its powers with the others.

\subsection{Working of the System}

It is reasonable to say that no system of government created can work efficiently without some high level of commitment of the operators of that system. However since operators (usually politicians) are human beings with different preferences, prejudices and even goals, there will be some areas where interest will diverge; some operators of the system will even attempt to make their position prevail at all time and at any cost. This definitely puts some strains on the entire government. It thus becomes inevitable for conflict-situation to be created, sometimes degenerating to conflict within and or against the system (Omar, 1999). In a presidential system certain conflict-situations are peculiar among the three organs of government while it can be said too that co-operation is not uncommon and in fact, a condition sine qua non for the system to be sustained. In the following discussion, it needs be stated that there are minor clashes between the judiciary and any of the two organs, such as refusal to obey court orders or the passing of retroactive legislation to render court judgment valueless, which are well known and therefore need not detain us, they certainly do not occur as often as the conflicts between the legislature and the executive do.

\section{STRUCTURE OF LOCAL GOVERNMENT}

Local government has a political structure and an administrative structure. The political structure is that within which the elected or selected political officials operate. It is a leadership structure for political office holders (Anyebe, 2013). On the other hand, the administrative structure consists of the departments in the local and how the personnel of local government use these to bring about services to the local people. In other words, it is the structure that houses the administrative personnel of the local government. It is actually the local government bureaucracy. Let us examine each of these structures.

\subsection{Political Structure}

The political structure of local government is meant for policy makers i.e. the political office holders. This structure plays two major roles, executive and legislative roles. The executive structure consists of the chairman of the local government, supervisors or supervisory councillors as the case may be, and the secretary also as the case may be. The legislative structure is the council. The council makes Laws and it contains principally elected representatives of the people from the various wards or constituencies in the local government. In some cases, the chairman is part of it, while in other cases; the chairman is not part of it. To understand these structures, their composition and their roles, we have to distinguish among the systems of leadership and the role of the chairman in each system. 


\subsubsection{The Parliamentary (Cabinet) System}

The major highlights of this system are as follows:

Every councillor is first elected to council as a legislator

$>$ The councillors in turn appoint a chairman to head the council from the majority party in council

The chairman appoints his supervisory councillors from among council members

The chairman, his supervisory councillors and other councillors are all legislators

$>$ The chairman, and his supervisory councillors are however the only members of the executive council (Finance and General Purposes Committee - F\&GPC).

The chairman and his supervisory councillors play both executive and legislative role

(In this system, the portfolio councillors play double role - legislative and executive).

\subsubsection{Presidential System}

The highlights of this system are as follows:

The chairman is elected directly by the electorate

There is a separate legislative and executive council

Only councillors belong to the legislative council

The chairman appoints his Supervisors from outside council members. A council member so appointed has to resign and his place filled through a bye-election.

$>$ The executive implement the Laws and policies of government and the council while the council makes Law and approves executive bills. The executive does not therefore perform legislative role while the legislature does not perform executive role (separation of powers).

Each organ of government (legislative or executive) serve as a check (or watchdog) against the activities of the other. (Checks and balance).

(In this system, the Councillors do not have any executive function, unlike in the cabinet system).

Figure 1 shows a diagram showing the political structure of Local Governments in Nigeria:



Figure1.

Source: Adapted from Anyebe, A. A. (2013) Operation of the Presidential System of Government

Level: The Executive and Legislative in Perspective

\subsubsection{Administrative Structure}

As pointed out earlier, the building blocks of the administrative structure of local government is the departments. In the Nigerian local government system, the tradition has in modern times (since 1976) favoured the establishment of six departments, (Even the Reforms of 1988 recommended between 4-6 departments for each Local Government).

The existing departments in the present local governments system are as follows:

Personnel Management (formerly Administration)

Finance \& Supplies (formerly Treasury)

Works

Agriculture and Natural Resources 
Primary Health Care (formerly Medical and Health)

Social Services or Social Development (consists of Adult Education, Community Development, Social Welfare, Youth \& Sports).

Planning, Research and Statistics

Under each department there are sections and below this there are units.

The first two departments are classified as Service departments since they provide the finance and maintain the personnel required in the other four departments. These other four departments are referred to as operational departments since their activities are more of delivering services on the field. These are the extension departments with their extension workers on the field.

Figure 2 shows a diagrammatic representation of the administrative structure.

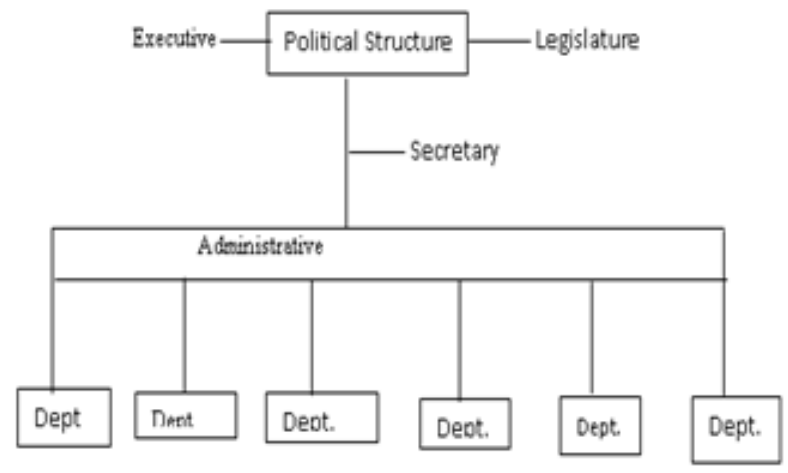

Figure2.

Source: Adapted from Anyebe, A. A. (2013) Operation of the Presidential System of Government

Level: The Executive and Legislative in Perspective

Note that the position of the secretary depends on the system practiced in the various states. In most presidential systems, the secretary is appointed by the chairman and he is largely an executive council member. He is a political appointee. In the parliamentary system especially as practiced between 1976 and 1991 and as a few states still practice today, the secretary is the head of administration and he is a career civil servant in the local government service.

The entire structure of local government can be displayed as follows:

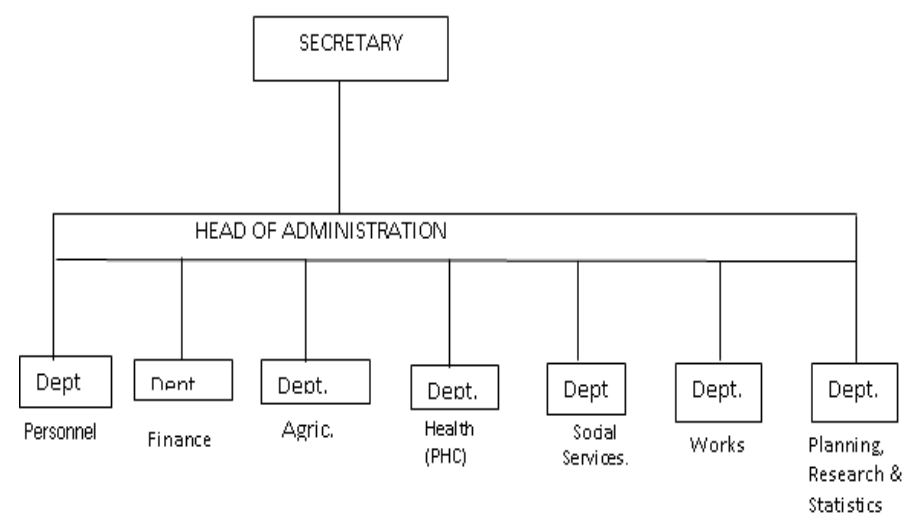

Figure3

Source: Adapted from Anyebe, A. A. (2013) Operation of the Presidential System of Government

Level: The Executive and Legislative in Perspective

Part of the structure of local government is the committee system. There are both statutory and ad hoc committees. A statutory committee is a mandatory one recognized by law which a local government must set up. Examples of these are the Finance and General Purposes Committee, an Education Committee, a Junior Staff Management Committee, a Peace and Security Committee, a PoliceCommunity Relations Committee. A brief note on the purpose of these committees is as follows: 
> Finance and General Purposes Committee - This is the cabinet or executive council of the local government which formulates financial policy for the Local Government.

Education Committee - Deals with basic education matters (primary and adult). It is normally chaired by the chairman or his councillor for education.

$>$ Junior Staff Management Committee - Responsible for the personnel matters of staff on grade levels 01-06.

Peace and Security Committee - comprises the representatives of the various spectra of community interests including security, business and religious. This is chaired by the local government chairman. The meeting holds once in a month and its agenda are the peace and security matters in the community.

Police/Community Relations Committee - Related to the above but more on the performance of the police in the area and how it can continuously enlist community support.

(Note that with the creation of the PHC Department, there is now a Local Government Primary Health Care Development Committee with similar structures at the District and Village levels. It is normally chaired by the Chairman with representatives from District and Village levels attending). Other committees could be Disciplinary Committee, Committees of the Legislative Council like the Monitoring Committee, Appropriation Committee, etc.

\section{ROLES AND RESPONSIBILITIES OF POLITICAL ACTORS (I.E. COUNCILlORS \& THE CHAIRMAN) IN LOCAL GOVERNMENTS}

The political actors in local government perform executive and legislative roles. In so doing, executive perform political, administrative and financial duties while the legislative perform the duties of Law-making, approval of executive bills, monitoring and financial duties (Anyebe, 2013).

Let us examine these duties in more detail.

\subsection{Councillors}

Generally, they are involved in policy-making, promulgation or enactment of bye-laws and making of rules and regulations governing the running of the affairs of the local government.

Their specific duties or functions are as follows:

Attending all meetings of the Local Government Council at least once in a month.

Serving as members of the Council sub-committees such as Committees for Education, Primary Health Care, Social Development, Works, Agriculture, Public Enlightenment, etc. to assist the whole Council in formulating its policies.

Liaising between the local government and their Constituencies on policy matters and to mobilize people's support for government and particularly local development.

In a separate document for the Presidential System, the financial duties or functions of the Legislature are outlined as follows:

debate, approve and possibly amend local government annual budgets, subject, however to the chairman's veto, which could be overridden by a two-thirds majority of the council;

$>$ vet and monitor the implementation of projects and programs in the local government annual budget;

$>$ examine and debate monthly statement of income and expenditure rendered to it by the executive arm of the local government;

performing such other functions as may be assigned to it from time to time by the state government.

\subsection{The Executive Council}

The Executive under the Parliamentary System is referred to as the Finance and General Purposes Committee (F\&GPC). Irrespective of the system, it performs the following functions:formulation of all policies, plans and programmes for the consideration and approval of the local government council; 
$>$ participation in management of the finances of the local government including:-

- Consideration of draft annual budget submitted by all Departments through the treasurer,

- Supervision of project implementation,

- ensuring that all monies due to the local government are collected, recorded and fully accounted for;

- ensuring that monthly statement of income and expenditure is prepared and forwarded to the Local Government Council;

- awarding of contract through competitive tendering.

\subsection{The Chairman}

The chairman is the chief executive and accounting officer of the local government. In that capacity he shall perform the following functions:

shall observe and comply with financial regulations governing receipt and disbursement of public funds and other assets entrusted to his care and shall be liable for any breach thereof;

shall direct the affairs of the local government and shall allocate responsibilities to the vice chairman, supervisors/supervisory councillors, and secretary to the local government;

shall convene and preside over the meeting of the Executive Committee of the local government at least once a week;

shall comply with the provisions of the Financial Memoranda regarding his fiscal responsibility. (Par. 1, 10, 1-13);

Overall, he is the chief security officer of the local government and that is why he heads the Security Committee of the local government.

\section{RELATIONSHIP BETWEEN POLITICAL OFFICE HOLDERS AND CAREER STAFF}

\subsection{General Administration}

The chairman is the overall head or leader of the local government. He controls both the political and the administrative structures. Virtually everybody is responsible to him. In running his administration, he appoints supervisory councillors who he places as political heads of departments just like a governor would appoint commissioners to head ministries. These supervisory councillors are the eyes and ears of the chairman in the departments. All decisions of the executive council or policies from the legislature concerning their respective departments are implemented through them. In the same token, they represent and present departmental problems, needs and views in form of memo at the executive council meetings. They have to defend such. The chairman therefore monitors the departments and policy implementation through these political heads. There are however certain regulations guiding his relationship with the administrative head of department. Example of this is, the political head does not sign cheques and shall not get involved in staff matters directly. A cordial working relationship is always advocated for both to make progress.

The chairman deals directly with the administration through the Secretary and the head of administration in purely administrative matters.

The chairman shall not dabble unnecessarily into the staff matters of officers of levels 07 and above. That is the preserve of the Local Government Service Commission.

\subsection{Financial Matters}

The following points are important:

$>$ The chairman is the Accounting Officer - he takes all the pains to be accountable.

Before any expenditure is made in local government, it must have been approved of by the Council in the annual local government estimates or budget of the local government.

$>$ The executive arm - prepares the local government estimates (budget) and submits to the legislative arm (Council) for approval. The approval of the budget by the Council signals the authority to incur expenditure (AIE) by the executive. 
$>$ Once the budget is approved by the legislature, the only control they have is in the monitoring of projects, and demanding for a monthly statement of income and expenditure of the local government from the executive.

The award of contract is entirely executive matter.

$>$ The chairman ensures "spending limits" of the different bodies and departments in local government are complied with.

$>$ The head of personnel/director of administration and the treasurer are the only signatory to local government cheques after the chairman approval. The elected officials are not allowed to sign local government cheque to ensure checks and balances.

Before any payment is made, there must be a voucher raised and before any cheque is raised the expenditure must have received the authorization of the chairman.

\subsection{Challenges}

Nigerian local government faces political, administrative, social and economic problems. Politically, the leadership has been very unstable over the years. This leadership comes with different names like democratic leadership, Sole Administrator, Management or Caretaker Committee etc. Even where the leadership is constitutionally recognized and given a tenure, they are often dissolved before the expirations of the tenure. Where this happens, to reconstitute them into democratic councils becomes a difficult task for the state governments. Most times the state governments are more comfortable with non-democratic leadership, than democratic ones as we have been living witnesses to the nonconstitution of democratic councils since they were dissolved early 2002. So also it was from $1979-$ 1983. The implication of such instability in government is that local governments do not have steady development plans as each leadership comes with its own agenda. Such does not encourage continuity in administration which does not create the right environment for development (Anyebe, 2013). There is also the failure on the part of legislature to exploit the instruments of checks and balances provided in Guidelines, rules and Procedures and constitution to check the excesses of the executive at times.

\section{CONCLUSION AND RECOMMENDATIONS}

The executive and the legislature at the local government level should imbibe the spirit of presidentialism. This entails the observance of separation of powers, i.e. they are not the extension of each other but independent entities. Finally, they should be presidential in their dealings with each other.

\section{REFERENCES}

Anyebe, A. A. (2013) Operation of the Presidential System of Government Level: The Executive and Legislative in Perspective, Being a paper presented at a National Seminar on Presidential System of Government at the Local Government Level, Organised by Leadership Newspapers Group Limited in conjuction with Leadership Conferences Limited at Peace Park (M \& M Event Centre) Beside NICON Luxury, Tafawa Balewa Way, Area 11, Garki-Abuja, Nigeria, $4^{\text {th }}-6^{\text {th }}$ December, 2013

Federal Republic of Nigeria (1987) Report of Political Bureau, Abuja.

Federal Republic of Nigeria: 1979 and 1999 Constitution.

Gboyega, A. (1987) Political Values and Local Government in Nigeria. Malthouse Press, Lagos, Nigeria.

Odoh, A. (1999) the Gains of Local Governments under the Military, the 1999 Constitution, and the Future of Local Government in Nigeria under Civil Democracy.

Okoli, F.C. (1998) An Introduction to the Theory and Practice of Local Government: A Nigerian Perspective. TOPMOST Printing Press, Nsukka, Nigeria.

Omar, M. (1999) Local Governments and the Challenges of our time; In the Training Manual of National Orientation for Local Government Councillors. Produced by the office of the Vice President, States, and Local Government affairs, Abuja. 